\title{
Mengenal Jejak Peninggalan Prabu Siliwangi di Kampung Adat Urug
}

\author{
Firman Syah ${ }^{\mathrm{a}, 1, *}$ \\ ${ }^{\text {a }}$ Program Studi MICE - Politeknik Negeri Jakarta \\ ${ }^{1}$ Email : firman_tegal@yahoo.com* \\ * corresponding author
}

\section{ARTICLE INFO}

\section{Keywords}

Culture tour,

Agriculture,

King Siliwangi,

Urug Indigenous Village, and Bogor

\begin{abstract}
The research activities carried out are of an inductive qualitative nature located in Urug Indigenous Village, Kiara Pandak Village, Sukajaya District, Bogor Regency, West Java. The informant chosen was Abah Ukat Raja Aya as a traditional figure. Primary data collected directly from informants in the form of questionnaires for direct interviews and supplemented by secondary data from literature studies.

As a trace of the legacy of King Siliwangi, Urug Indigenous Village is one of the areas included in the category of cultural tourism destinations, namely the Ministry of Education and Culture with Cultural Institution Number: LK20181124000302 with the proposer being Abah Ukat Raja Aya. For this reason, this research was conducted to find out the history of the birth of the Urug Indigenous Village and the cultural model preserved by the Urug Indigenous Village.

The results show that the history of the birth of the Urug Indigenous Village is derived from the word 'teacher', which is an acronym form of digugu and imitated meaning can be trusted and made a role model. As for the journey the origin of the teacher's name because it was deliberately hidden or disguised so as not to be known, the letter ' $g$ ' moved back to Urug. The cultural model preserved by the First Urug Indigenous Village in terms of hereditary leadership, the existence of a large house as a center of authority for traditional leadership, and the lives of people who have a livelihood from planting to harvesting rice.
\end{abstract}

\begin{abstract}
ABSTRAK
Kegiatan penelitian yang dilakukan bersifat kualitatif induktif dengan berlokasi di Kampung Adat Urug, Desa Kiara Pandak, Kecamatan Sukajaya, Kabupaten Bogor, Jawa Barat. Adapun informan yang dipilih adalah Abah Ukat Raja Aya sebagai tokoh adat. Data primer yang dikumpulkan langsung dari informan berupa angket untuk wawancara langsung dan ditambah data sekunder dari studi pustaka.

Sebagai jejak peninggalan Prabu Siliwangi, Kampung Adat Urug merupakan salah satu wilayah yang masuk kategori destinasi wisata budaya, yaitu di Kementerian Pendidikan dan Kebudayaan dengan Nomor Lembaga Kebudayaan: LK20181124000302 dengan pengusul adalah Abah Ukat Raja Aya. Atas dasar itulah penelitian ini dilakukan untuk mengetahui sejarah kelahiran Kampung Adat Urug dan model kebudayaan yang dilestarikan oleh Kampung Adat Urug.

Hasil menunjukkan bahwa sejarah kelahiran Kampung Adat Urug berasal dari kata 'guru', yang merupakan bentuk akronim dari digugu dan ditiru artinya dapat dipercaya dan dijadikan panutan. Adapun dalam perjalanannya asal muasal nama guru karena sengaja disembunyikan atau disamarkan supaya tidak diketahui, maka huruf ' $g$ ' nya pindah ke belakang jadi Urug. Model kebudayaan yang dilestarikan oleh Kampung Adat Urug pertama segi kepemimpinan secara turun temurun, adanya rumah besar sebagai pusat kewenangan kepemimpinan adat, dan kehidupan masyarakat yang memiliki mata pencaharian menanam hingga memanen padi.
\end{abstract}




\section{PENDAHULUAN}

Kampung Adat Urug merupakan salah satu wilayah yang berada di Desa Kiara Pandak, Kecamatan Sukajaya, Kabupaten Bogor, Jawa Barat. Untuk menuju lokasi diperlukan jarak tempuh sekitar 42 KM dari Cibinong tepatnya ke arah barat. Dari pertigaan Kecamatan Cigudeg, dilanjutkan ke arah barat daya menuju Kecamatan Sukajaya sekitar 15 KM, dan berlanjut sekitar 9 KM untuk sampai di lokasi. Sepanjang perjalanan menuju Kampung Adat Urug yang merupakan sisa peradaban Prabu Siliwangi di masa silam ini, jalanan yang dihadapi sangat berbelok-belok dan naik turun mengikuti lereng bukit dengan badan jalan yang sempit. Tak heran bila di sepanjang perjalanan terdapat dua mobil yang berbeda jalur, seringkali salah satu mengalah untuk berhenti sejenak. Penerangan jalan juga masih minim bahkan beberapa titik belum terpasang. Sepanjang jalan menuju Kantor Desa Kiara Pandak sudah beraspal, walau sebagian besar rusak berat. Adapun dari kantor desa menuju Kampung Adat Urug sudah beraspal dengan kondisi cukup baik.

Seperti diketahui, Kampung Adat Urug merupakan salah satu wilayah yang masuk kategori destinasi wisata budaya. Sehingga bagi wisatawan yang ingin menemukan alternatif rekreasi unik di Bogor Barat, tepatnya Kecamatan Sukajaya, dapat merasakan tatanan kehidupan masyarakat yang penuh dengan kearifan lokal dalam mempertahankan tradisi keramahtamahan masyarakat. Ditambah dengan kondisi alam yang masih alami dan terjaga ini, akan menambah daya tarik wisatawan untuk mengamati dan mengetahui lebih dalam kehidupan masyarakat adat. Kampung Adat Urug bahkan sudah masuk pelestarian warisan budaya di Kementerian Pendidikan dan Kebudayaan dengan Nomor Lembaga Kebudayaan: LK20181124000302. Pengusul Kampung Adat Urug sendiri yang tercatat dan saat ini sebagai pemangku adalah Abah Ukat Raja Aya. Itu mengapa setiap wisatawan yang melakukan kunjungan ke Kampung Adat Urug senantiasa diarahkan dan melakukan dialog dengan Abah Ukat tersebut.

Terdapat beragam kebudayaan sejak masa silam terus dilestarikan keberadaannya hingga saat ini. Di antaranya Upacara Sedekah Bumi, yang dilaksanakan setiap satu tahun sekali dan tidak dipastikan kapan harus dilaksanakan. Karena hanya saat waktu sebelum menebar padi. Kemudian ada Upacara Seren Taun, yaitu upacara yang dilaksanakan setelah panen. Juga Salametan Ngabuli (upacara tutup tahun) dilaksanakan pada Bulan Muharram di Gedong Sanghyang Tunggal sekaligus menyambut tahun baru. Ketiga acara tersebut dilaksanakan bukan di hari libur dan jatuh pada hari Rabu. Sementara dua acara lain, yakni Salametan Maulud yang dilaksanakan di Ruang Pancaniti Gedong Sanghyang Tunggal. Selamatan ini adalah untuk memperingati kelahiran Nabi Muhammad SAW. Termasuk Upacara Ruwah yang dilaksanakan setiap tanggal 12 dengan tujuan untuk "rewah" pada Nabi Adam, memperingati karuhun Adam dan keturunannya dilaksanakan sesuai tanggal yang tertera dalam kalender.

Dibutuhkan strategi khusus yang dilaksanakan untuk mengembangkan destinasi wisata budaya. Sekaligus ada usaha untuk melestarikan nilai-nilai yang sudah menjadi tradisi masyarakat lokal. Sehingga di masa datang para generasi muda akan mengetahui kilas balik sebuah kebudayaan yang dipegang teguh untuk kepentingan bersama. Kepedulian ini tentu datang dari kemauan masyarakat lokal karena sudah menjadi warisan leluhur juga destinasi wisata budaya. Beragam strategi untuk melestarikan kebudayaan yang dipilih sebuah destinasi wisata tidak terlepas dari peluang dan tantangan yang sedang dihadapi. Terlebih kehadiran website sangat membantu sebuah informasi untuk bisa benar-benar sampai ke seluruh lapisan masyarakat. Sehingga pemilihan model dalam rangka memperkenalkan kebudayaan perlu dipertimbangkan secara maksimal. Atas dasar itulah lahir keinginan penulis untuk melakukan kajian mengenai Kampung Adat Urug dengan judul "Mengenal Jejak Peninggalan Prabu Siliwangi di Kampung Adat Urug".

Atas dasar pemikiran tersebut penulis mengajukan beberapa pertanyaan, yaitu:

a. Bagaimana sejarah kelahiran Kampung Adat Urug?

b. Bagaimana model kebudayaan yang dilestarikan oleh Kampung Adat Urug?

\section{TINJAUAN TEORITIS}

Beragam kebudayaan, tradisi, keindahan alam, kerajinan dan lain yang menjadi identitas suatu pulau merupakan sebagian kecil kekayaan yang dimiliki Indonesia. Bahkan, pada satu pulau dapat dijumpai perbedaan yang ada antara satu daerah dengan daerah lain. Inilah yang menjadikan Indonesia sebagai bangsa berdaulat. Sebagaimana semboyan negara, Bhinneka Tunggal Ika (Syah, 2014). Sehingga kebudayaan menjadi salah satu daya tarik wisata yang dapat dikedepankan saat ini. Tidak lain supaya masyarakat Indonesia pada umumnya, dan masyarakat lokal khususnya, memiliki pemahaman dan pengetahuan yang lebih dalam tentang aneka ragam kebudayaan di Indonesia. Bagaimanapun juga nilai-nilai yang melekat 
sehingga menjadi sebuah tradisi jelas memiliki nilai yang luar biasa. Ketika konsep ini dibangun secara utuh justru para wisatawan terutama mereka (budayawan maupun peneliti) yang cinta akan kebudayaan suatu daerah akan berdatangan untuk mempelajari bahkan mengikuti perkembangan dari masa ke masa.

Budaya adalah sumber daya wisata dengan tradisi panjang, hadiah hidup, dan masa depan yang menjanjikan. Pada awal abad ke-21, wisata budaya sangat populer, dan pada saat yang sama hampir seluruh daerah merekam tingginya jumlah pengunjung acara festival, pameran seni, dan konser. Semakin banyak penyedia kegiatan perjalanan budaya mendorong yang menguntungkan, menyebabkan peningkatan persaingan di daerah wisata budaya dari tahun ke tahun (Steinecke, 2010). Dalam situasi ini, penyedia kegiatan perjalanan budaya dan pendidikan memerlukan informasi pasar yang kekinian untuk mengembangkan strategi bisnis yang sukses dengan kelompok sasaran berorientasi pada pemasaran. Beberapa dekade terakhir, pariwisata telah menyusun berbagai survei penelitian terkait alasan perjalanan. Dua pertiga dari orang di Jerman memiliki kemauan untuk belajar lebih banyak tentang perjalanan budaya selama liburan. Para wisatawan bersemangat dan penasaran, walau mereka termasuk yang tidak ahli tentang sejarah, seni, dan budaya. Wisatawan tersebut hanya ingin melihat sesuatu yang mengesankan, mendapatkan tayangan baru, dan diinformasikan secara menghibur.

Maka lahirnya kelurahan/desa memiliki peluang untuk mengembangkan wilayah menjadi destinasi wisata. Diperlukan dasar-dasar kajian dalam sebagai data awal untuk studi kelayakan sebelum memutuskan konsep dan langkah menjadikan kelurahan/desa wisata selanjutnya. Melalui analisa yang tajam atas setiap persoalan, akan mampu melahirkan konsep yang utuh dan mendekati sempurna. Sebab, semua data akan dicari kelemahan hingga detail (Syah, 2014). Produk wisata yang dapat dijual oleh kelurahan/desa wisata sangat beragam. Ini diketahui seiring dengan perkembangan model destinasi wisata yang terdapat pada kelurahan/desa. Di antara ragam wisata yang menarik dijual adalah wisata petualangan, wisata agro, wisata bahari, wisata kuliner, wisata budaya, wisata sejarah, dan wisata kreatif. Walau di luar jenis wisata tersebut, kelurahan/desa juga dapat menemukan konsep wisata sesuai kebutuhan dengan memertimbangkan potensi kelurahan/desa yang mampu digali.

Pola kerja yang diterapkan oleh masing-masing desa dengan didampingi pemerintah daerah setempat setidaknya mampu memperkecil arus urbanisasi, membantu mengentaskan kemiskinan, dan meningkatkan kreativitas karena pintu lapangan pekerjaan mulai terbuka lebar (Syah, 2017). Salah satu contoh pengembangan desa wisata yang berhasil adalah Desa Penglipuran di Kabupaten Bangli, Provinsi Bali. Desa adat yang mengandalkan kebudayaan ini mampu menyedot wisatawan mancanegara. Dari luas 112 hektar tersebut hanya 12 hektar saja yang menjadi tempat tinggal rumah penduduk. Sisa lahan masih memiliki fungsi alami, seperti hutan bambu seluas 37 hektar dan 49 hektar diperuntukkan sebagai ladang. Alasan utama desa yang terletak 700 meter di atas permukaan laut itu memiliki aturan yang ketat dan untuk menebang pohon bambu tidak boleh sembarangan tanpa izin dari tokoh masyarakat setempat (www.penglipuran.net). Artinya, konsep desa pelestarian alam terpadukan dengan konsep pengembangan ekonomi lokal.

Selain alam seperti pegunungan, perbukitan, hutan, danau, sungai, dan pantai yang dapat dipergunakan sebagai aset destinasi wisata bagi masyarakat desa adapula potensi lain yang mampu dibangun dan dikembangkan. Yaitu, unsur kebudayaan yang berasal dari peninggalan sejarah, tradisi, nama daerah, suku yang mendiami, dan sebagainya. Semua kebudayaan tersebut biasanya dilestarikan masing-masing desa dan sudah membudaya. Sehingga teramat sulit untuk ditinggalkan. Bahkan, mereka yang tergolong generasi muda dan belum tentu tahu asal muasal kebudayaan tersebut juga mengikuti aturan tersebut sebagai bentuk penghargaan atas apa yang sudah mengakar di seluruh lapisan masyarakat desa. Termasuk juga hukum adat dimana keputusan bersama yang disepakati seluruh tokoh di desa dan kemudian diiyakan oleh masyarakat untuk melaksanakan keputusan tersebut.

Tinggal bagaimana konsep yang dibangun dan dikembangkan oleh seluruh lapisan masyarakat dengan berpedoman pada UU Nomor 10 Tahun 2009 tentang Kepariwisataan. Ada satu aturan yang dapat dijadikan pedoman untuk melaksanakan kegiatan kemasyarakatan sesuai dengan potensi masing-masing daerah. Sehingga ada satu kesatuan persepsi yang melibatkan banyak pihak. Mulai dari pemerintah, masyarakat, dan para investor dalam mencapai tujuan akhir kesejahteraan masyarakat (Syah, 2017). Hal ini sesuai dengan temuan Cerro and et al. (2017) bahwa warga merupakan bagian penting dari destinasi wisata. Hal ini untuk mendapatkan pemahaman sikap masyarakat yang lebih terhadap pengembangan destinasi wisata. Sikap yang diperlukan dari masyarakat supaya menguntungkan dan dapat berkontribusi pada kesuksesan destinasi wisata. Dapat ditafsirkan masyarakat lokal harus diberikan pemahaman dan pengetahuan yang baik dalam 
usaha untuk mengembangkan destinasi wisata melalui persepsi yang dimiliki masyarakat pedesaan terkait niat dalam mendukung model pariwisata yang berkelanjutan.

Pendapat tersebut dipertajam oleh Arbogast et al. (2017) dimana pengelolaan tujuan pedesaan dihadapkan pada tantangan cukup besar karena untuk mempromosikan kemakmuran ekonomi melalui pariwisata. Seperti yang terjadi pada salah satu desa di Tucker County, West Virginia. Tantangan terbesar adalah menjaga keaslian dan tempat, diversifikasi ekonomi, upah yang masih rendah, dan karyawan yang kurang, menghubungkan resor dengan usaha kecil dan komunitas, dan membangun visi bersama, identitas, serta koordinasi. Selain juga yang diperhatikan oleh pedesaan adalah peran pemasaran, tujuan pemasaran, mengejar target pasar, meminimalkan dampak negatif pariwisata, menghargai keunikan kawasan, koordinasi, kerjasama, serta kemitraan antara pelaku bisnis, pemerintah, dan pengusaha pariwisata pedesaan.

Mak et al. (2017) juga menyetujui jika partisipasi masyarakat merupakan strategi penting untuk pengembangan pariwisata berkelanjutan di masyarakat pedesaan. Partisipasi masyarakat tersebut masuk di tingkat yang berbeda (baik lokal, regional, maupun nasional) dan dalam keadaan tertentu. Melalui partisipasi masyarakat, pengembangan pariwisata akan lebih kuat karena menggabungkan beragam pendapat masyarakat lokal yang dapat membantu memenuhi harapan mereka selaku pelaku usaha pariwisata pedesaan. $\mathrm{Hal}$ ini jelas membuat masyarakat lebih mendukung pengembangan pariwisata karena benar-benar memiliki kesempatan berpartisipasi dalam proses perencanaan dan pembangunan hingga evaluasi pariwisata pedesaan. Konsep ini termasuk membantu dalam menciptakan masyarakat yang lebih demokratis.

Oleh karena itu, tinggal memperbaiki sistem informasi yang ada di desa wisata. Dengan demikian segala bentuk informasi yang menyangkut desa wisata secara menyeluruh mudah diperoleh oleh wisatawan di segala penjuru. Hal ini tentu akan meningkatkan percepatan pembangunan dan perekonomian yang cukup besar. Dalam memberikan informasi kepariwisataan yang relevan, diperlukan suatu media elektronik yang dapat membantu mempromosikan sekaligus menyebarluaskan secara luas sebuah keindahan dan keunikan yang ada. Salah satu media yang dapat membantu mempromosikan dan memberikan informasi yang banyak digunakan oleh masyarakat termasuk destinasi wisata di era sekarang adalah website (Syah, 2017). Termasuk di dalamnya pembenahan sarana dan prasarana serta fasilitas bagi wisatawan. Sebagai contoh di Kampung Adat Urug adalah akomodasi, jalan raya desa, penerangan jalan, serta transportasi sehingga memudahkan wisatawan ketika melakukan kunjungan. Terlebih wisata yang ditawarkan oleh Kampung Adat Urug adalah wisata budaya yang memiliki daya pikat dalam melestarikan tradisi masyarakat lokal.

Ketika program kepariwisataan sudah berjalan dengan baik di suatu desa wisata, misal pada beberapa destinasi wisata yang ada di Kabupaten Gunungkidul maka saat musim liburan atau akhir pekan destinasi wisata penuh dengan wisatawan. Bahkan sampai ada yang tak mampu menampung wisatawan (Syah, 2017). Dengan harapan ketika sistem online sudah berjalan dengan baik, seluruh pihak yang berkepentingan dapat mengetahui secara detail berapa banyak destinasi wisata, pada jam berapa bisa masuk lokasi, dan terutama daya tampung masing-masing destinasi wisata. Juga ragam cenderamata yang disediakan dan dijual kepada wisatawan, apalagi sudah ada wisatawan asal mancanegara sebanyak 3\% hingga 5\% yang datang dari Cina, Korea, Jepang, dan Eropa. Sistem online di Kabupaten Gunungkidul yang sudah terintegrasi dengan baik dan lengkap menghasilkan informasi detail mengenai ekowisata unggulan. Ini juga menjadi alternatif komunikasi pemasaran ekowisata ke semua pihak baik di dalam maupun luar negeri untuk mengetahui potensi di Kabupaten Gunungkidul. Diharapkan muncul rasa ingin tahu dan berminat melakukan kunjungan.

Sementara untuk di Kabupaten Bogor diakui masih minim wisatawan dari mancanegara. Dari 8 juta wisatawan baru sekitar 5000 pengunjung yang berstatus warga negara asing dengan didominasi oleh Timur Tengah. Termasuk bentuk dukungan yang diberikan pemerintah kepada masyarakat lokal adalah untuk mengembangkan konsep wirausaha (Syah, 2017). Pemerintah Kabupaten Bogor memberikan peluang yang besar kepada masyarakat di desa-desa dengan potensi wisata untuk belajar (studi banding) ke daerah di luar Kabupaten Bogor. Melalui studi banding ke Desa Wisata Cibuntu di Kuningan misalnya, masyarakat diharapkan dapat memahami segala aspek yang harus diperhatikan dalam membangun dan mengembangkan desa wisata. Sekaligus di bidang manajemen pengelolaan destinasi wisata yang saat ini lebih ke arah sistem informasi. Sehingga, beberapa waktu ke depan desa-desa wisata dapat meniru bahkan bisa melebihi dalam hal kemajuan dan pengembangan yang baik. Diakui, berwisata ke Kabupaten Kuningan tidak lengkap rasanya jika tidak mengunjungi Desa Wisata Cibuntu. Sebuah desa wisata yang termasuk unik, karena di lingkungan desa banyak ditemukan situs-situs purbakala. Konon desa tersebut sudah ada sejak zaman batu (Megalitikum). Hal ini terlihat dari jejak yang masih ada berupa kuburan batu dan masuk dalam situs purbakala di Kabupaten Kuningan. 


\section{METODOLOGI PENELITIAN}

Untuk mendukung kegiatan penelitian yang dilakukan, peneliti menggunakan kualitatif. Sehingga dalam memperoleh data yang akurat dan terkini, penulis secara langsung terjun di lapangan. Lokasi yang dipilih oleh peneliti adalah Kampung Adat Urug, Desa Kiara Pandak, Kecamatan Sukajaya, Kabupaten Bogor, Jawa Barat. Informan yang dipilih adalah Abah Ukat Raja Aya sebagai tokoh adat. Oleh karena itu, peneliti menggunakan metode kualitatif induktif. Analisis data secara induktif ini digunakan karena beberapa alasan. Pertama, proses induktif lebih dapat menemukan kenyataan-kenyataan jamak sebagai yang terdapat dalam data. Kedua, analisis induktif lebih dapat membuat hubungan peneliti-responden menjadi eksplisit, dapat dikenal, dan akuntabel. Ketiga, analisis demikian lebih dapat menguraikan latar secara penuh dan dapat membuat keputusan-keputusan tentang dapat-tidaknya pengalihan pada suatu latar lainnya. Keempat, analisis induktif lebih dapat menemukan pengaruh bersama yang mempertajam hubungan-hubungan. Kelima, analisis demikian dapat memperhitungkan nilai-nilai secara eksplisit sebagai bagian dari struktur analitik (Moleong, 2012: 10).

Dengan demikian, metode kualitatif yang digunakan merupakan sebuah prosedur penelitian untuk menghasilkan data deskriptif berupa kata-kata tertulis maupun lisan dari orang-orang maupun perilaku yang dapat diamati. Dimana penelitian kualitatif berusaha melihat kebenaran-kebenaran, bahkan melihat sesuatu yang bersifat tersembunyi kemudian melacak lebih jauh atas sebuah kenyataan tersebut. Penelitian dilakukan untuk mengidentifikasikan jejak peninggalan yang ada di Kampung Adat Urug melalui dua jenis data, yaitu:

1. Data primer yang dikumpulkan langsung dari informan. Angket yang diajukan dalam bentuk beberapa pertanyaan tertulis dan dilakukan melalui wawancara langsung supaya memperoleh gambaran yang jelas mengenai Kampung Adat Urug. Kedua, observasi lapangan untuk mengetahui kondisi lingkungan yang ada di Kampung Adat Urug.

2. Data sekunder yaitu data internal dan data eksternal dari studi pustaka untuk memperoleh gambaran aspek teoritis yang jelas dengan mengumpulkan bahan-bahan tertulis terkait. Seperti, jurnal-jurnal, surat kabar, undang-undang, materi kuliah, serta tulisan lain yang menunjang dan terkait penelitian yang dilakukan.

Disimpulkan, metode kualitatif ini mengutamakan manusia sebagai instrumen penelitian. Karena instrumen penelitian yang digunakan adalah manusia, maka sebagai alat utama yang digunakan adalah wawancara. Dimana instrumen penelitian ini dapat berkembang sesuai dengan situasi dan kondisi di lapangan untuk menentukan cara mencari, mengumpulkan, mengolah dan menganalisis data hasil penelitian tersebut. Penelitian kualitatif ini dapat digunakan untuk memahami interaksi sosial, misalnya dengan wawancara mendalam sehingga akan ditemukan pola-pola yang jelas. Dengan kalimat lain, metode kualitatif ini bergantung pada pengamatan peneliti. Penelitian tersebut dilakukan terhadap latar alamiah atau lingkungan sosial yang menghasilkan data deskriptif berupa kata-kata, gambar, dan bukan angka-angka.

Setelah seluruh data diperoleh dari lapangan, maka langkah selanjutnya adalah analisis data. Teknik analisis data kualitatif menurut Bognan \& Biklen (1982) sebagaimana dikutip Moleong (2012: 248) adalah upaya yang dilakukan dengan jalan bekerja dengan data, mengorganisasi data, memilah data menjadi satuan yang dapat dikelola, mensintesiskan, mencari, dan menemukan pola, menemukan apa yang penting dan apa yang dipelajari, dan memutuskan apa yang dapat diceriterakan kepada orang lain. Langkah-langkah yang dilakukan melalui:

a. Membaca/mempelajari data, menandai kata-kata kunci dan gagasan yang ada dalam data.

b. Mempelajari kata-kata kunci itu, berupaya menemukan tema-tema yang berasal dari data.

c. Menuliskan 'model' yang ditemukan.

d. Koding yang telah dilakukan.

\section{HASIL DAN PEMBAHASAN}

\section{a. Sejarah Kampung Adat Urug}

Kampung Adat Urug menjadi salah satu desa wisata yang mengedepankan unsur-unsur kebudayaan. Sehingga adat istiadat yang dipegang benar-benar masih asli dan belum tersentuh oleh modernisasi. Urug disebut kampung adat karena tidak ada perubahan kecuali bangunan pemukiman masyarakat sekitar. Sementara lokasi yang ditempati Abah Ukat selaku pemangku adat setempat masih termasuk bangunan lama. 
Itu mengapa bangunan tersebut masuk kategori cagar budaya. Bahkan, pada 2019 ini, akan diusulkan menjadi salah satu destinasi yang memperoleh bantuan dari pemerintah Kabupaten Bogor untuk diajukan kepada Pemerintah Provinsi Jawa Barat. Selanjutnya jika diterima maka akan diajukan ke tingkat nasional yakni sesuai dengan rekomendasi dari Presiden RI untuk kemudian dipromosikan ke tingkat internasional. Sehingga tidak saja wisatawan asal Indonesia saja yang berdatangan, namun banyak pula wisatawan mancanegara yang kemudian melakukan kunjungan ke Kampung Adat Urug.

Saat diamati dengan seksama, bangunan yang ditempati Abah Ukat berasal dari konstruksi bangunan rumah tradisional Kampung Adat Urug. Secara umum, wisatawan yang berkunjung dapat menemukan sambungan kayu yang sama dengan sambungan kayu tersebut sama dengan sambungan kayu yang terdapat pada salah satu bangunan di Cirebon yang merupakan sisa-sisa peninggalan Kerajaan Pajajaran. Jadi, keduanya adalah peninggalan Kerajaan Pajajaran. Itu mengapa sejarah Kampung Adat Urug juga tak bisa dilepaskan dari sejarah Prabu Siliwangi yang kisahnya melekat dengan kebudayaan dan adat setempat. Sejak Abah Ukat menempati bangunan yang sarat budaya di Kampung Adat Urug tersebut, mulai ada keterbukaan antara tokoh adat setempat dengan pemerintah. Tujuan dari kedekatan dan keakraban yang dibangun tersebut tidak lain untuk adanya kejelasan dan pengakuan yang resmi dari pemerintah selaku pemegang kepentingan di Indonesia. Abah Ukat mengakui hanya sebatas ingin mengetahui kejelasan sebagai saksi dari unsur pemerintah bahwa apa yang dilakukan dan dikerjakan serta dijalani oleh dirinya dan umumnya masyarakat adat di Kampung Adat Urug benar-benar sesuai dengan kategori cagar budaya. Namun, tetap tidak melanggar peraturan agama atau peraturan negara yang notabene tetap menjadi salah satu rujukan supaya tidak ada tata aturan adat istiadat dan kebudayaan yang melanggar. Ternyata konsep saya diakui jadi memang tidak ada aturan adat dan budaya yang melanggar.

Diresmikan pada 2010 lalu, Kampung Adat Urug menjadi cikal bakal masyarakat, budaya, tradisi yang melekat erat dengan lingkungan dan alam di sekitarnya. Urug berasal dari kata 'guru', yang merupakan bentuk akronim dari digugu dan ditiru artinya dapat dipercaya dan dijadikan panutan. Adapun dalam perjalanannya asal muasal nama namanya guru karena sengaja disembunyikan atau disamarkan supaya tidak diketahui, maka huruf ' $g$ ' nya pindah ke belakang jadi Urug. Jadi ketika suatu saat muncul istilah guru lagi, jangan ada yang takut karena memang Abah Ukat selaku pemangku adat yang memunculkan. Ada alasan mendasar mengapa kampung tersebut disebut kampung guru. Tidak lain karena masyarakat setempat percaya bahwa mereka berasal dari keturunan Prabu Siliwangi, raja di Kerajaan Pajajaran, Jawa Barat. Prabu Siliwangi sudah beberapa kali 'tilem' atau menghilang karena dikejar-kejar untuk masuk dan memeluk Agama Islam. Dan di Gunung Gede Pangrango inilah menjadi akhir pelarian Prabu Siliwangi, tepatnya di Kampung Adat Urug. Jadi bisa dikatakan masyarakat di Kampung Adat Urug merupakan keturunan Prabu Siliwangi dari Kerajaan Padjajaran.

Sehingga dapat dikatakan bahwa Kampung Adat Urug ini merupakan peninggalan Prabu Siliwangi, terlebih terdapat petilasan bekas Prabu Siliwangi yang bisa membuktikan menurut silsilah sejarah. Hanya saja Abah Ukat belum dapat mengakui keaslian atau tidaknya cerita tersebut, hanya saja secara garis keturunan sejarah tersebut turun temurun hingga sampai ke telinga Abah Ukat. Mengenai silsilah Kampung Adat Urug, dapat diketahui dari dua buku. Pertama, berjudul Kasepuhan yang Tumbuh di atas yang Luruh "Pengelolaan Lingkungan Secara Tradisional di Kawasan Gunung Halimun Jawa Barat" yang ditulis oleh Kusnaka Adimiharja. Kedua dalam buku Sanghyang Raja Uyeg "dari sakral ke profan" karya Arthur S Nalan. Dalam kedua buku ini kampung Adat Urug ditulis sedikit, sebagai salah satu Kampung Adat atau Kasepuhan. Seperti Kasepuhan lainnya di Jawa barat, Kasepuhan Urug mempunyai hubungan dengan kerajaan Pajajaran (1482-1579 M). Buku yang pertama objek kajiannya difokuskan pada Kasepuhan Bungur di wilayah Sukabumi dalam pengelolaan lingkungan secara tradisional. Sementara buku Kedua membahas kesenian teater rakyat yang berasal dari masyarakat Kasepuhan kaitannya dalam penanaman padi dan cerita Dewi Sri. Adapun mengenai studi tentang kepemimpinan tradisional pada suatu Kampung Adat, penulis menemukan judul sebuah buku "Kasepuhan Sirnaresmi: Studi Tentang Kepemimpinan Tradisional di Sukabumi Selatan" yang ditulis oleh Yudistira Garna tahun 1973, dari judul itu bisa diketahui bahwa objek kajiannya berada di Kasepuhan Sirnaresmi Sukabumi (Dewantara, 2013: 92-93).

Bukti lain adalah adanya Cadas Koneng yang berada tak jauh $( \pm 400 \mathrm{~m})$ dari kediaman Abah Ukat. Situs batu tapak tapak tersebut ditemukan oleh orang yang saat itu mencari lahan untuk Kampung Adat Urug, yakni masih beberapa generasi lagi sebelum Prabu Siliwangi. Kampung Adat Urug mulai bertambah tenar sejak 2004 sejak Abah Ukat mulai menjadi pemangku adat. Saat itu, Abah Ukat masih mengatur perjalanan dan pada 2005 mulai ada yang melakukan perjalanan ke Kampung Adat Urug, tahun berikutnya (2006) wisatawan yang datang dari penjuru negeri dan pada 2008 sudah ada wisatawan mancanegara. Sekitar Agustus 2017, ada 25 pelajar dari Jepang yang juga mengadakan kunjungan ke Kampung Adat Urug untuk 
mengetahui secara langsung adat istiadat yang ada di sini. Jika dijelaskan induk kebudayaan ada di Kampung Adat Urug. Dimana wilayah tersebut menjadi cikal bakal sebuah adat istiadat. Bahkan tidak diperbolehkan untuk melecehkan, saling caci maki, dan lain sebagainya antar agama. Oleh karena itu semua bangsa dan agama harus tetap dirangkul menjadi satu kesatuan. Misalnya adanya pesta seren taun di semua wilayah mengikuti tradisi dan kebudayaan yang ada di Kampung Adat Urug sebagai cikal bakal. Mulai dari aturan hingga tata cara menurut sejarah bermula dari Kampung Adat Urug. Hanya saja kemudian menyebar ke Tanah Jawa itu dibawa oleh putra Prabu Siliwangi (Prabu Kian Santang) sebelum mengislamkan di Cirebon dengan membuat struktur organisasi terlebih dulu. Dengan alasan jika sampai ke Majapahit maka keberadaan dirinya akan diketahui banyak pihak.

Dengan benar-benar memegang erat kebudayaan daerah justru menggiring Kampung Adat Urug ke arah yang lebih maju. Sebab, jika bukan masyarakat lokal sendiri yang menjaga tak akan muncul Kampung Adat Urug sebagai salah satu cagar budaya yang didirikan dan diresmikan oleh pemerintah. Sehingga kebudayaan lokal di sini secara otomatis akan musnah dari peradaban. Jika dijelaskan induk kebudayaan ada di Kampung Adat Urug. Dimana wilayah tersebut menjadi cikal bakal sebuah adat istiadat. Bahkan tidak diperbolehkan untuk melecehkan, saling caci maki, dan lain sebagainya antar agama. Oleh karena itu semua bangsa dan agama harus tetap dirangkul menjadi satu kesatuan. Misalnya adanya pesta seren taun di semua wilayah mengikuti tradisi dan kebudayaan yang ada di Kampung Adat Urug sebagai cikal bakal. Mulai dari aturan hingga tata cara menurut sejarah bermula dari Kampung Adat Urug. Hanya saja kemudian menyebar ke Tanah Jawa itu dibawa oleh putra Prabu Siliwangi (Prabu Kian Santang) sebelum mengislamkan di Cirebon dengan membuat struktur organisasi terlebih dulu. Dengan alasan jika sampai ke Majapahit maka keberadaan dirinya akan diketahui banyak pihak. Dikutip dari Dewantara (2013: 96), Kampung Adat Urug ini adalah tempat pulang Prabu Siliwangi. Setibanya di Kampung Adat Urug, Prabu Siliwangi mempunyai tiga orang putra. Pertama laki-laki, kedua perempuan, dan yang ketiga laki-laki. Prabu Siliwangi memberikan mandat atau amanatnya untuk mewarisi dan menjaga Kampung Adat Urug kepada putra yang ketiga. Makam dari putra yang ketiga tersebut berada di tepi kali Cidurian. Sementara putri kedua "dihijrahkan" ke daerah Leuwi Catang, arah gunung Pongkor dan putra yang pertama ke Lebak Larang arah Pelabuhan Ratu, terus ke Pasir Jeungjing - Bojongcisono Tegallumbu - Talaga - Sirnaresmi Ciganas - Ciptarasa - Ciptagelar, Sukabumi. Jadi kasepuhan yang tersebar di beberapa daerah di Sukabumi tersebut awalnya dari Urug.

b. Model Kebudayaan

Ada beberapa kebudayaan yang memang dipegang teguh oleh masyarakat di Kampung Adat Urug. Misal dari segi kepemimpinan, dimana masyarakat Kampung Adat Urug memiliki Ki Kolot (Abah Ukat) sebagai pihak yang memegang kendali, memperhatikan, dan mempertahankan adat istiadat yang ada di Kampung Adat Urug secara turun temurun. Istilah Ki Kolot berbeda dengan puun yang ada di suku Baduy. Jika sering melakukan perjalanan ke timur (Cirebon) maka penelitian akan jelas yang menyatakan hal ini. Ada sebagian yang menjelaskan bahwa Prabu Siliwangi masuk Islam di Cirebon dan ada yang mengatakan tidak sampai Cirebon. Lalu mereka yang sampai Cirebon adalah anaknya yakni Prabu Kian Santang yang kemudian mengislamkan tanah jawa di Cirebon. Sementara Prabu Siliwangi tak sempat masuk Islam. Sebagai penerus leluhur dan Ki Kolot, saat ini Abah Ukat menempati sebuah rumah besar atau Gedung Agung yang merupakan pusat kewenangan kepemimpinan adat. Bangunan tersebut sudah dikategorikan lama namun baru dipugar dan diresmikan oleh pemerintah sejak 2010. Kemudian pada 2017 lalu melalui tahap rehab ulang bangunan. Dana segar dari pemerintah pun digelontorkan dan setiap dua tahun bisa kembali diajukan.

Artinya, dana sebagai modal awal dalam pelaksanaan pembangunan dan pengembangan suatu destinasi wisata sangat dibutuhkan. Anggaran akan menjadi penting karena tanpa didukung pendanaan yang memadai konsep awal membuat destinasi wisata dikhawatirkan tidak sesuai rencana (Syah, 2014). Penggunaan dana juga semestinya dilaksanakan seefektif dan efisien mungkin sesuai yang tertera di dalam rencana awal. Jika pemerintah daerah dinilai kurang dapat mengelola dengan baik, destinasi wisata tersebut dapat diserahkan kepada pihak swasta. Dengan catatan terdapat Master of Understanding (MoU) di antara keduanya yang berisi hak dan kewajiban secara detail. Terutama lama periode pengelolaan destinasi wisata oleh swasta. Jangan sampai dipegang pihak swasta tanpa adanya tempo tertentu, karena menyebabkan Pemda kehilangan peluang besar dalam mengelola destinasi yang terdapat di daerah. Sebaliknya, jika dirasa mampu melaksanakan segala kegiatan pemasaran pariwisata, Pemda bisa mengambil kembali destinasi wisata tersebut. Tentu dengan tetap melaksanakan pengembangan supaya lebih dikenal oleh wisatawan nusantara, bahkan wisatawan mancanegara.

Seperti ini pula yang bisa dilakukan oleh Kampung Adat Urug. Sampai saat ini jika ada yang bertanya mengenai keaslian bangunan ini Abah Ukat mengaku tidak mengetahui secara pasti dan belum berani 
bertanggung jawab. Sebab tidak sedikit pihak yang merekayasa atau mengada-ngada cerita. Namun jika dirunut secara sejarah, bangunan yang ditempati memang tergolong asli. Rumah yang saat ini ditempati pun diisi bukan oleh orang sembarangan. Mereka harus keturunan dari Prabu Siliwangi yang menjadi kokolot berdasarkan wangsit. Nanti, rumah ini akan diwariskan ke anak laki-laki Abah Ukat, namun tergantung petunjuk atau wangsit yang akan dia dapat. Walau Kampung Adat Urug terbilang luas dari sini sampai ke Kantor Desa yang terbagi atas Urug Tonggoh (atas) dipimpin oleh Abah Kayod, Urug Tengah (Tengah) dipimpin oleh Abah Amat, dan Urug Lebak (Bawah) sebagai pusat dipimpin oleh Abah Ukat yang sekaligus masuk kategori cagar budaya.

Dengan demikian, adanya dua bangunan lain yang masih sama dengan bangunan ini juga tergolong asli hanya saja yang ditempati Abah Ukat merupakan 'bin'. Adat istiadat yang dimaksud seperti seren tahun, ruwatan, atau memperingati hari-hari besar Islam. Secara khusus, yang menjadi fokus Kampung Adat Urug menjadi cagar budaya adalah bidang pertanian. Dimana, masyarakat yang hidup di lingkungan tersebut memiliki mata pencaharian menanam hingga memanen padi. Kegiatan yang dilaksanakan oleh masyarakat Kampung Adat Urug hanya sebatas itu dan padi lokal masih dipertahankan untuk ditanam oleh Abah Ukat. Abah Ukat mengaku belum pernah memperkenalkan cara menanam padi ke zaman modern saat ini. Bagaimanapun model adat yang dipertahankan dan menjadi salah satu cagar budaya dianjurkan oleh pemerintah daerah sehingga Kampung Adat Urug masih terus mempertahankan tradisi yang sarat dengan nilai-nilai peninggalan leluhur. Abah Ukat sendiri masih melakukan tanam bibit setiap satu tahun sekali. Dilanjutkan membuat beras dari bahan dasar padi yang sudah matang belum dan tidak menggunakan jasa penggilingan, karena alami sehingga padi masih ditumbuk. Untuk memasak beras menjadi nasi saja masih menggunakan kayu bakar sebagaimana tradisi yang sudah dipegang secara turun temurun.

Apa yang dilakukan tersebut tidak lain karena Abah Ukat merasa patuh karena aturan yang sudah dibuat, taat karena perintah yang sudah tertulis baik secara agama, adat, maupun negara. Sebagai generasi ke 11 dari para penerus leluhur, Abah Ukat berani mengutarakan segala informasi yang semasa bapak atau kakeknya belum berani memberikan informasi tersebut. Jadi, jika ada orang yang bertanya, selalu dijawab tidak tahu dengan alasan belum saatnya. Nanti suatu saat ada yang menjelaskan. Jadi ini memang keberanian abah Ukat sejak menjadi penghuni sekaligus pemangku adat karena memang tidak melanggar peraturan yang ada. Hal ini juga disaksikan oleh Direktorat Pendidikan dan Kebudayaan yang ketika datang ke Kampung Adat Urug dan menyaksikan kegiatan kebudayaan yang ada di lokasi tersebut mengakui keaslian. Seperti saren taun yang diadakan 19 Desember lalu setelah Dhuhur. Adapun rangkaian kegiatan tersebut tidak lain doa bersama masyarakat Kampung Adat Urug. Hanya saja seluruh masakan yang berasal dari masyarakat secara bersama-sama dihidangkan (dibawa keluar rumah dan dikumpulkan) berjajar memanjang sampai ke bawah. Sajian yang dikeluarkan tergantung pada masing-masing kemampuan yang dimiliki individu masyarakat di Kampung Adat Urug. Tepat setelah Dhuhur semua hidangan dikumpulkan dan kemudian dilakukan pembacaan doa serta makan bersama. Kegiatan tersebut biasanya diadakan sebelum Abah Ukat menanam padi. Ada istilah 'mipit kudu amit, ngala kudu menta, nyaur kudu diukur' yang berarti jika kita menanam padi hingga panen, maka kita harus minta izin kepada yang kuasa karena Dialah yang memberikan kehidupan, bicara dengan seperlunya dan bicara baik-baik.

Dengan kalimat lain, harus dilakukan kegiatan meminta izin terlebih dulu sebelum memulai kegiatan menanam padi. Diharapkan umumnya masyarakat di Kampung Adat Urug jangan sampai kegiatan menanam padi menghadapi kegagalan baik terserang hama atau penyakit lain yang ditakutkan masyarakat. Alhamdulillah, selama ini Abah Ukat bersama masyarakat Kampung Adat Urug belum sampai mengalami gagal panen di seluruh wilayah Kampung Adat Urug. Seperti diketahui, saking luasnya Kampung Adat Urug itulah luas sawah membentang yang merapat di pinggiran dimana garapan masyarakat Kampung Adat Urug sampai menerobos ke tujuh desa. Bahkan lahan sawah terus bertambah seiring dengan warga yang menjual sawah karena enggan menyangkul. Jadi bukan penyerobotan garapan warga, yang ada hanya saja ada orang yang tidak suka menanam padi akhirnya lahan mereka dijual. Sementara mereka ada yang pergi ke kota walau sedikit, ada juga yang mencari mata pencaharian lain sampingan seperti ikan basah, roti, soto mie, maupun bakso. Karena menunggu waktu panen padi antara 6 bulan sampai 1 tahun bukan waktu yang sebentar. Jadi, sudah bisa menanam padi setiap satu tahun saja sudah Alhamdulillah masih bisa makan. Berbeda dengan wilayah lain yang menanam padi bisa sampai 3 kali dalam setahun.

Walau demikian, stok padi yang dimiliki Abah Ukat tak mengalami kekurangan walau usia sudah berpuluh tahun. Tak heran bila setiap bangunan yang ada di Kampung Adat Urug memiliki seni tersendiri yakni memiliki kolong dan lumbung padi yang bernama leuit. Dalam tradisi Kampung Adat Urug merawat leuit menunjukkan betapa berharga bangunan mungil untuk bisa ditempati bersama keluarga. Beberapa di antaranya lengkap dengan sepasang alat tumbuk berupa lesung dan alu. Dalam Bahasa Indonesia sering 
disebut lumbung padi. Setiap lumbung rata-rata memiliki luas $2 \times 3$ meter dan tinggi total 4 meter dengan bahan bangunan berupa kayu dan bilik. Keharusan menyimpan padi di lumbung tersebut dilakukan sampai aturan tentang hari pengambilan dikeluarkan. Inilah tradisi yang kemudian ditaati hingga diwariskan kepada generasi berikutnya. Di Kampung Adat Urug, hukum adat diturunkan lintas generasi secara lisan. Oleh karena itu, Abah Ukat sebagai pemangku adat di Kampung Adat Urug, menyebut aturan tersebut sebagai Kitab Carék yang berarti ucapan bernada larangan. Dimana aturan tersebut sudah ada sejak masa kerajaan.

Inilah salah satu kategori wisata budaya yang dapat dikembangkan oleh salah satu daerah. Terlebih sudah diakui oleh Kementerian Pendidikan dan Kebudayaan. Untuk itu, tinggal bagaimana pemerintah desa setempat bersama pemangku adat melakukan pengaturan untuk menghasilkan model wisata budaya yang dapat dikembangkan. Jika sudah terlihat dengan baik produk yang disajikan, tinggal meningkatkan sisi pengemasan sehingga lebih menarik wisatawan untuk datang ke Kampung Adat Urug. Tujuan akhir adalah selain nilai-nilai kebudayaan dan sejarah tetap terus berdiri kokoh dan masyarakat lokal memiliki peluang mendapatkan masukan dari bisnis yang dikelola. Sehingga akan benar-benar memberi manfaat untuk kesejahteraan rakyat, berkeadilan, kesetaraan, dan proporsionalitas sesuai dengan prinsip yang didengungkan dalam UU No 10 Tahun 2009 tentang Kepariwisataan. Salah satu langkah yang dapat dilakukan adalah dengan melakukan pembinaan terhadap masyarakat yang ada dalam mengelola Kampung Adat Urug. Pola kerja utama dalam membentuk masyarakat dalam menciptakan sebuah destinasi wisata adalah dari, oleh, dan untuk masyarakat (Syah, 2014).

Istilah Pendapatan Asli Daerah (PAD) dengan sendirinya akan dirasakan oleh masyarakat lokal di Kampung Adat Urug. Karena saat ini tidak sedikit daerah-daerah di Indonesia mulai menggenjot beragam cara dan kegiatan untuk memaksimalkan PAD (Syah, 2014). Semakin besar PAD yang didapat, akan semakin menguatkan jatidiri sebagai daerah yang mandiri. Melalui PAD yang diperoleh tersebut, pembangunan di daerah akan semakin gencar dilaksanakan. Sehingga, dalam beberapa waktu ke depan daerah tersebut akan menjadi maju. Beragam kegiatan perekonomian yang menunjang daerah terlaksana dengan baik. Akhirnya, 'pintu' lapangan pekerjaan mulai terbuka lebar dan ikut membantu daerah dalam meningkatkan taraf hidup masyarakat sekitar. Terlebih konsep yang ditawarkan oleh Kampung Adat Urug ini satu-satunya yang ada di Bogor Barat. Dasar pengambilan keputusan untuk pengembangan Kampung Adat Urug sebagai desa wisata berbasis budaya juga dilihat dari Undang-Undang Dasar Republik Indonesia (UUD RI) 1945 Pasal 33 Ayat 3 berbunyi: 'bumi, air, kekayaan alam di dalamnya, dikuasai negara dan digunakan untuk sebesar-besar kemakmuran rakyat.' Landasan tersebut menjadi acuan yang baik untuk membangun dan mengembangkan kelurahan/desa demi kemajuan dan kemakmuran masyarakat bersama. Sehingga arti kata penguasaan pada UUD RI 1945 dapat berarti pengaturan, pembinaan, pengembangan, dan pengawasan.

\section{PENUTUP}

Dari pembahasan di atas dapat disimpulkan bahwa:

a. Sejarah kelahiran Kampung Adat Urug berasal dari kata 'guru', yang merupakan bentuk akronim dari digugu dan ditiru artinya dapat dipercaya dan dijadikan panutan. Adapun dalam perjalanannya asal muasal nama guru karena sengaja disembunyikan atau disamarkan supaya tidak diketahui, maka huruf ' $\mathrm{g}$ ' nya pindah ke belakang jadi Urug.

b. Model kebudayaan yang dilestarikan oleh Kampung Adat Urug pertama segi kepemimpinan memiliki Ki Kolot (Abah Ukat) sebagai pihak yang memegang kendali, memperhatikan, dan mempertahankan adat istiadat yang ada di Kampung Adat Urug secara turun temurun. Kedua sebuah rumah besar atau Gedung Agung yang merupakan pusat kewenangan kepemimpinan adat yang baru dipugar dan diresmikan 2010. Ketiga adalah kehidupan masyarakat memiliki mata pencaharian menanam hingga memanen padi dengan terus mempertahankan tradisi (peninggalan) leluhur.

Beberapa saran yang diberikan adalah:

a. Bagi pemerintah dan stakeholder (Kampung Adat Urug), dapat memasarkan potensi yang dimiliki melalui website supaya lebih banyak wisatawan yang mengetahui wisata budaya.

b. Bagi ilmu pengetahuan, dapat menambah khazanah keilmuan seputar kepariwisataan khususnya di bidang kebudayaan.

c. Bagi peneliti selanjutnya, dapat mengembangkan temuan lebih luas lain dari artikel ini yang baru membahas histori dan kekayaan budaya yang dimiliki oleh Kampung Adat Urug. 


\section{DAFTAR PUSTAKA}

Arbogast, Doug, et al. 2017. DMOs and Rural Tourism: a Stakeholder Analysis the Case of Tucker County, West Virginia. in Sustainability 9 (10). DOI: 10.3390/su9101813. pp. 1-18.

Cerro, AM Campon and et al. 2017. Sustainable Improvement of Competitiveness in Rural Tourism Destinations: The Quest for Tourist Loyalty in Spain. in Journal of Destination Marketing \& Management 6 (3), pp. 252-266.

Dewantara, Asep. 2013. Peran Elit Masyarakat: Studi Kebertahanan Adat Istiadat di Kampung Adat Urug Bogor. Buletin Al-Turas, Vo.1. 19, No. 1. journal.uinjkt.ac.id/index.php/al-turats/article/view/3703.

Mak, AHN, et al. 2017. The Effects of Food-Related Personality Traits on Tourist Food Consumption Motivations. Asia Pacific Journal of Tourism Research, 22 (1), pp. 1-20.

Moleong, Lexy J. 2012. Metodologi Penelitian Kualitatif. Bandung: Remaja Rosdakarya.

Steinecke, A. 2010. Trends and Issues in Global Tourism. in link.springer.com, pp. 185-196

Syah, Firman. 2017. Model Ekonomi Kreatif pada Bisnis Ekowisata Gunung Kidul. dalam Prosiding Seminar Institut STIAMI. Jilid 4 Terbitan 1 halaman 85. https://lppm.stiami.ac.id/wp/?page_id=326

Syah, Firman. 2017. Sistem Destinasi Pariwisata di Kabupaten Bogor Jawa Barat. dalam Majalah Ilmiah Bijak 14 (2), 149-161. http://ojs.stiami.ac.id/index.php/bijak/article/view/13

Syah, Firman. 2017. Strategi Mengembangkan Desa Wisata. dalam Prosiding Seminar Nasional Multi Disiplin Ilmu \& Call for Papers UNISBANK Ke 3 (Sendi_U 3). https://www.unisbank.ac.id/ojs/index.php/sendi_u/article/view/5048

Syah, Firman. 2014. Destinasi Wisata Sebagai Aset Daerah. detikNews. https://news.detik.com/opini/2595172/destinasi-wisata-sebagai-aset-daerah

Syah, Firman. 2014. Membangun Konsep Kelurahan/Desa Wisata. detikNews. https://news.detik.com/opini/d-2586516/membangun-konsep-kelurahandesa-wisata

Undang-Undang Nomor 10 Tahun 2009 tentang Kepariwisataan.

Website www.penglipuran.net diakses 15 Januari 2019.

Website www.dapobud.kemendikbud.go.id/lembaga-budaya diakses 10 Januari 2019. 